\title{
JUURNAL.RU
}

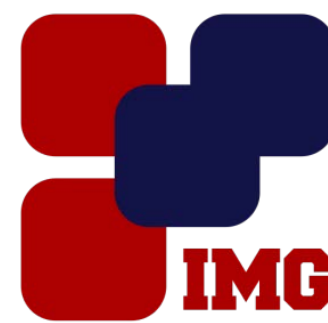

Iyanoy
Management
GRoup

Верба Л.П. МБУЗ ЦРБ Усть-Донеикого района Ростовской области Ростов-на-Дону, Россия

doi: 10.18411/lj-30-11-2016-1-03

idsp 000001:lj-30-11-2016-1-03

\section{Причины затруднения носового дыхания}

Нарушения носового дыхания принимают участие в патогенезе развития многих заболеваний уха, нижних дыхательных путей, сердечно-сосудистой, пищеварительной и других систем [1]. В связи с этим, проблема укрепления здоровья как детского, так и взрослого населения включает в себя санацию верхних дыхательных путей, тем более что заболевания носа и околоносовых пазух (ОНП) занимают одно из первых мест в структуре ЛОР заболеваний. Количество больных с заболеваниями носа и ОНП не имеет тенденции к сокращению [2]. Более того, отмечается его неуклонный рост не только в нашей стране, но и в мире [3, 4]. Хроническими формами ринита страдает 10-20\% населения, а его симптомы в эпидемиологических исследованиях отмечаются у $40 \%$ опрошенных [5]. Ринологические больные составляют абсолютное большинство госпитализированных в ЛОР стационары. В то же время, в литературе имеются лишь отдельные сведения о распространенности отдельных заболеваний носа и околоносовых пазух.

Целью исследования явилось изучение структуры патологии ЛОР органов, приводящей к затруднению носового дыхания, по данным амбулаторного приема.

Анализ основных причин затруднения носового дыхания проведен за период с января 2015 по октябрь 2016 года. В анализируемую группу включены все больные, обратившиеся к ЛОР врачу, независимо от основного диагноза. Отбор больных проводился на основании жалоб больных на затруднение 
носового дыхания, анамнеза, данных осмотра (наружный осмотр, проекции околоносовых пазух, передняя и задняя риноскопия), по показаниям: рентгенография или компьютерная томография околоносовых пазух, консультация ЛОР аллерголога.

Общее число амбулаторных больных, включенных в изучение структуры заболеваемости, составило 623 (детей в возрасте от 3 до 14 лет - 101, взрослых в возрасте от 19 до 76 лет - 522).

Структура заболеваемости зависела от возраста больных, что отражено в таблицах 1 и 2.

Таблий 1.

Основные причины затруднения носового дыхания у детей от 3 до 14 лет.

\begin{tabular}{|c|c|c|}
\hline Нозологические единицы & $\begin{array}{c}\text { Количество } \\
\text { случаев }\end{array}$ & $\%$ \\
\hline Искривление перегородки носа & 10 & $10,0 \%$ \\
\hline Острый и хронический риносинусит & 17 & $17,0 \%$ \\
\hline Хронический аденоидит & 33 & $33,0 \%$ \\
\hline Сезонный аллергический ринит & 6 & $6,0 \%$ \\
\hline Аденоиды & 34 & $34,0 \%$ \\
\hline & 101 & $100 \%$ \\
\hline
\end{tabular}

Лидирующую позицию среди причин затруднения носового дыхания у детей занимает патология носоглотки: суммарно аденоиды и аденоидиты составляют $67 \%$ от общего числа исследованных, что совпадает с данными других авторов [6, 7, 8].

Таблийа 2.

Основные причины затруднения носового дыхания у взросльх.

\begin{tabular}{|c|c|c|}
\hline Нозологические единицы & $\begin{array}{c}\text { Количество } \\
\text { случаев }\end{array}$ & $\%$ \\
\hline Искривление перегородки носа & 106 & $20,6 \%$ \\
\hline Острый синусит & 99 & $19,6 \%$ \\
\hline Сезонный аллергический ринит & 91 & $17,7 \%$ \\
\hline Хронический синусит (обострение) & 70 & $13,6 \%$ \\
\hline Полипозный риносинусит & 37 & $7,1 \%$ \\
\hline Круглогодичный аллергический ринит & 26 & $5,1 \%$ \\
\hline Вазомоторный ринит & 24 & $4,6 \%$ \\
\hline Хронический гипертрофический ринит & 21 & $4,1 \%$ \\
\hline Аденоиды & 13 & $3,2 \%$ \\
\hline Острый ринит & 9 & $1,8 \%$ \\
\hline Прочие & 26 & $2,6 \%$ \\
\hline Всего & 522 & $100 \%$ \\
\hline
\end{tabular}

У взрослых ведущее место по причинам затруднения носового дыхания занимают искривление перегородки носа - 20,6\% и острых риносинусит $19,6 \%$. 
У 9 больных, отнесенных к разряду «прочие», при осмотре был выявлен вторичный атрофический ринит, причинами которого были повторные хирургические вмешательства в полости носа. При осмотре у этих больных отмечено патологическое расширение носовых ходов. В этих случаях ведущее значение для экспертной оценки имеет передняя активная риноманометрия [9, 10], которая позволяет выявить увеличение воздушного потока в полости носа.

Обращение за медицинской помощью по поводу сезонного аллергического ринита в течение изучаемого периода было неравномерным. Для Ростовской области наиболее тяжелым является летнее-осенний период поллиноза с конца июля по октябрь, вызванный цветением сорных трав. Наибольшее количество обращений приходится на сентябрь (до $26 \%$ от общего числа больных с затрудненным носовым дыханием).

Таким образом, основными причинами затруднения носового дыхания у взрослых являются искривление перегородки носа и острые риносинусит, у детей первое место среди причин затруднения носового дыхания занимает патология глоточной миндалины. 


\section{Литература}

1. Руководство по ринологии. Ппод ред Г.З Пискунова. М.: «Литтерра», $2011.959 \mathrm{c}$.

2. Стагниева И.В. Вегетативная дисфункция в проявлении про-зопалгии у больных с риносинуситами. Мед. вестник Юга России. 2012. № 2. С 67-69.

3. Стагниева И.В., Симбирцев А.С. Роль цитокинов в патогенезе лице-вой боли при риносинусите. Медицинская иммунология. 2015. Т. 17. № S. C. 319.

4. Бойко Н.В., Стагниева И.В. Дифференциальная диагностика лице-вых болей. Рос. ринология. 2012. Т. 20. №4. С. 39-41.

5. Мареев О.В., Луцевич С.И., Мареев Г.О., Ивлев И.И. Дифференци-альная диагностика хронического гипертрофического ринита при помощи лазерной доплеровской флоуметрии // Материалы XVII съезда оторинолар. России. Нижний Новгород, 7-9 июня 2006. - СПб, 2006. - С. 304-305.

6. Бойко Н.В., Бачурина А.С., Жданов А.И. Профилактика послеоперационных кровотечений при аденотомии. Рос. ринология. 2015. T. 23. № 2. С. 26-30.

7. Бойко Н.В., Бачурина А.С. Аденотомия и аденотонзиллотомия у детей с затруднением носового дыхания. Рос. ринология. 2015. Т. 23. № 1. С. 9-12.

8. Зарубин С.С., Дегтева Г.Н., Калинин М.А. Распространенность хронической ЛОР патологии $\mathrm{y}$ детей, посещающих дошкольные учреждения г. Архангельска // Рос. оторинолар. - 2006. - № 5. - С. 76-80.

9. Пискунов Г.З., Пискунов С.3. Клиническая ринология. - М.: «Мик-лош», 2002. - 390 c.

10. Бойко Н.В., Колесников В.Н. Клиническая ценность передней активной риноманометрии. Российская ринология. 2006. № 3. С. 4-7. 